This is an Author's Accepted Manuscript of an article published in Sexuality and Disability, Vol. 30, No. 2 (2012) p. 209-225, http://dx.doi.org/10.1007/s11195-011-9239-z

Springer $\odot$, the final publication is available at: www.springerlink.com

(Access to the published version may require subscription)

\title{
“I Want to Do IT Right!” A Pilot Study of SWEDiSh SeX Education and Young PEOPle With InTELLECTUAL DISABILITIES
}

\author{
LOTTA LÖFGREN MÅRTENSSON
}

\begin{abstract}
In Sweden sex education has been compulsory since 1955. However, access to sex education seems to be insufficient in schools with special education programs. Concerns about unwanted pregnancies, sexual abuse and sexual risk situations make personnel insecure about how to best deal with the subject. A largely heteronormative perspective of sex education renders young gay people with ID an invisible group. Stereotyped gender norms where girls are supposed to be oriented towards love and relationships and boys towards sexuality make it more difficult for young people with ID to find a more subtle way to act. The aim of this study is to strengthen sexual health among young people with ID, and to develop a knowledge base culled from their own experiences that can help teachers in special schools to supply sufficient sex education. What are the experiences of sex education in young people with ID aged 16-21? In what way, and by whom, should sex education be supplied? What themes do the young people with ID consider important? Qualitative research interviews with 16 young females (9) and males (7) with ID aged 16-21 years have been conducted. Guiding the analyses is an interactionist perspective on sexuality. Results show that a restrictive script is geared toward informants with ID, focusing on sexual risks instead of challenging a discourse of pleasure, desire and intimacy. The study also shows that using critical pedagogy can help personnel develop a professional and adequate teaching model for sex education at schools for adolescents with ID.
\end{abstract}

\section{KEYWORDS}

Sex education Intellectual disability Special schools Norm critical pedagogy Sweden

\section{INTRODUCTION}

In 1948, the World Health Organization affirmed the right to sexual health for all, which is defined as "a state of physical, emotional, mental and social well-being related to sexuality" [1]. The rights include, inter alia, to seek, receive and acquire information in relation to 
sexuality and sex education. But what really constitutes the right to sexual health and sex education for young people with intellectual disabilities (ID) in practice?

Sex education was made compulsory as early as 1955 in the Swedish school system $[2,3]$, but the students' access to information about their own bodies, sexuality and relationships still appears to be deficient in high school special education programs [4]. The national standards of sex education are too general, and the aim of providing a quality curriculum is difficult to attain; nor are the standards adapted to the varying developmental, maturational and intellectual levels of this particular population [5]. Even if the most important transmission of knowledge occurs in schools, peer groups and parents also have considerable influence on young people's knowledge, attitudes and behaviors [6]. Because of the impact of intellectual disability, young people with ID do not enjoy the same opportunities as others to share information and knowledge with one another [4].

Staff in special schools and rehabilitation centers certainly believe that it is important for young people with ID to acquire a comprehensive sex education, but ambivalence runs high [7]. Concerns about unwanted pregnancies, sexual abuse and other sexual high risk situations engenders doubt concerning what, how and who should convey this knowledge.

The accessibility of online pornography and its impact on youth is another area that creates anxiety among adults [8]. Adolescents with ID are considered to be particularly exposed and vulnerable to gender-stereotyping and unrealistic images of men, women and sexuality [9]. Even if the majority of young people have developed strategies to deal with this without being adversely affected, there is a minority of young people who engage in risky behavior affecting their sexual health [8]. These individuals are at risk in social, economic and psychological contexts [10]; many in this population category also have an intellectual disability [11].

\section{Previous ReSEARCH}

The overt bias of schools to provide heteronormative sex education based on heterosexual families or couples has attracted much attention in recent years [2]. For young people with ID who find themselves in a position of dependence, it can become particularly difficult to find alternative ways of being and living [4, 7]. Intellectual disability is seen as sufficiently "different" and sexual orientations and gender identities other than the heteronormative are rendered invisible $[12,13]$. For young people with disabilities, it can thus be more difficult than for others to "come out" as lesbian, gay, bisexual or transgender [14]. Contemporary Swedish schools also appear to reinforce gender-stereotyped traits where girls are supposed to be love and relationship-oriented, while boys are seen as appetitive, drive-oriented and therefore constitute the norm for sexuality [2]. We do not know specifically how this affects young people with ID who grow up in female-dominated care settings, yet we do know that it does affect them $[15,16,4]$.

EDUCATION, PRACTICE AND INSTRUCTION IN SEX EDUCATION 
Current sex education in Swedish schools is focused on dialogue, discussion and the examination of values in sex and relationships, in order for the students to practice selfreflection and become aware of their values and feelings when confronted with various concerns and situations [2]. One of the few educational models developed to target young people with ID is ASRE, Adapted Sex and Relationship Education [ASS, Anpassad Sex och Samlevnadskunskap] [17, 7]. In this modality, flexibility is stressed, the breadth of different sexual expressions and directions is examined, and attention is directed toward individual differences and a variety of life experiences. The heterogeneity in the varying degrees of intellectual disability contributes to the importance of defining sexuality as "broader than just intercourse," i.e. it includes flirting, touching, body-to-body contact, masturbation, petting, kissing, etc. The provision of knowledge should therefore be adapted to the different maturity levels, life experiences, techniques and materials, and be realistic, based on the individual's unique life situation.

Staff in Swedish special education schools, care settings and rehabilitation facilities still lack education, training methods and supervision when teaching sex and relationship issues $[18,7]$. In addition, parents' negative reactions, the attitudes of colleagues as well as society's prejudices lead to difficulties in conducting sex education in special schools [18]. Collectively, this means that young people with ID do not have the same access to sex education as their peers, and they may be compromising their sexual health due to lack of familiarity with their own physical functions, different sexualities, risk-taking and of sexual and romantic relationships. Moreover, formal knowledge of the subjective experiences of sex education in this population is almost non-existent.

\section{OBJECTIVES AND RESEARCH QUESTIONS}

The main objective of the pilot study is to improve the sexual health of young people with ID, and to develop knowledge that can be beneficial for staff in special education schools and rehabilitation activities in the provision of sex education. Specifically, the aim is to create in-depth knowledge of the adolescent's own experiences of sex education (its content, communication, methods, etc.). Based on the gathered data, the next step would be to test and subsequently improve the existing ASRE model $[17,7]$. The following research questions were formulated for this first step:

- What experiences do people 16-21 years old with intellectual disabilities (ID) have of sex education?

- How and by whom do adolescents with ID believe that sex and relationship education should be taught and/or communicated?

- Are there relevant factors that contribute to the adequacy of sex education and if so, what are these factors according to adolescents with ID?

\section{THEORETICAL CONSIDERATIONS}

\section{SEXUAL SCRIPTS}


The study is based on an interactionist perspective of sexuality [19]. Specifically, Sexual Script Theory or SST [20] is used as the basis of understanding and describing experiences of sexual health and knowledge related to sex and relationship issues among young people with ID. Scripts can be seen as manuscripts for sexual acts; they help provide insight into the complexity of human sexuality, since they often provide answers to fundamental questions such as when, how, where, with whom and why. Scripts can also be divided into collective, interpersonal and intrapsychic levels (ibid.). Cultural, collective scripts affect overall societal values regarding sexuality while external, interpersonal scripts organize relationships between people according to society's basic norms. Conversely, internal, intrapsychic scripts specify how an individual should act and react in particular situations. Postmodern society is characterized by cultural scripts of parallel, often conflicting norms and behavioral patterns $[21,8]$. Adolescents with ID are not only bound by these cultural norms, but also by any staff or caregiver's view of sexuality, which has been shown to contain ambivalence and rather restrictive rules of conduct and guidelines for sexual activities $[4,9]$. Finally, the adolescents must relate to their own intrapsychic scripts, which contain their individual experiences of sexual health, sex education, sexual experiences and sexual risktaking.

\section{METHODOLOGY, IMPLEMENTATION AND SELECTION}

Qualitative research interviews were conducted in order to obtain in-depth knowledge of the adolescents' subjective experience of sex education. The method is specifically adapted to the purpose of probing deeply and capturing the more complex aspects of experiences of sexual health and knowledge about sex and relationship issues [22,23]. The interview technique is non-directive and flexible, which is particularly suitable for informants with ID. However, research focusing on the voices of people with ID is still unusual. There are several reasons for this issue; many informants tend to respond tersely with simple phrases or single words, which means that the interviews often must be guided, with answers becoming brief [24]. The varying degrees of limited linguistic ability also restrict the sample to those who can express themselves better verbally, which is slightly over a third of this entire group [25]. Moreover, available research points to the confounding phenomenon known as "yes-saying," idyllization and the so-called "interviewer effect" (ibid.). These represent tendencies to respond affirmatively to questions regardless of their content, and the desire to provide an image of reality that corresponds to idealization or wishful thinking. The interviewer effect describes a reluctance to criticize anyone upon whom one is dependent. Moreover, it may be extra difficult for the respondent to comment on a research area such as sexuality, when the topic seems abstract and stirs emotions and experiences that are often complex [4]. Overall, these aspects are therefore important to keep in mind as a researcher in interview situations.

The selection of informants was made by postal service mailings to the principals at special education high schools in Malmoe, Sweden. In addition to the introductory letter in the solicitation packet, an easy-to-read invitation letter was directly addressed to students with intellectual disabilities. The intention was to gain a breadth of demographic factors such as gender, ethnicity, class, degree of disability and varying ages between 16-21 years. 
The final sample consists of 16 students, seven boys and nine girls aged 16-21 years. These students who attend national and individual programs in senior high schools have varying degrees of intellectual disabilities. ${ }^{1}$

In five cases, interviews with consenting informants occurred with the collaboration of a graduate student of gender studies, described as "R" in the study, and who had working experience of the topic. All informants are indicated with an "I" and senior researchers as "SR." The interviews were 15-40 minutes in length and took place in private rooms at the various schools. They were recorded on tape and transcribed verbatim. The interviews were thematically organized according to the research questions in order to provide a basis for the next step in the study, with the intention of providing a model of sex education that will be tested and developed in collaboration with students in special education programs.

\section{ETHICAL ASPECTS}

The ethical aspects of the study were conducted in accordance with the Swedish Scientific Council guidelines for information, consent, confidentiality and use requirements [26]. Informed consent was sought both orally and in writing. Students were advised of the right to terminate participation without explanation and that the information supplied was treated confidentially. In this study, the focus was on the informants' experience of sex education and not their own private sexuality, which means that the interview questions were not likely perceived as particularly intimate. During the interview process, however, a few participants still construed the meeting as more therapeutic than research oriented, and disclosed their own sexual experiences. Thus it became important for the researcher to clarify the purpose of the meeting and in some cases refer informants to other specialists.

\section{PROCESSING AND ANALYSIS OF THE INTERVIEWS}

The analysis is empirical and oscillates between examining parts/quotes and complete expressions in the interviews [see 27]. The latter concerns a combination of the informant's body language, tone and verbal expressions, etc. Descriptive results were chosen according to the theoretical starting point and then presented based on a) informant's experience of sex education, b) what informant learned/wanted to learn c) the ways in which information was learned, and d) by whom and when information should be given [cf. 20].

In order to maintain confidentiality, informants are presented only by gender and age. In some cases, names of high school programs are disclosed, in addition to the informant's background in terms of experiences of educational institutions and/or curricula. The

\footnotetext{
${ }^{1}$ A secondary special education school will offer national, special and individual programs in Sweden. The different programs are mainly focused on career preparation (http://www.skolverket.se) Accessed 27 May 2011.
} 
intention is to create a greater understanding of the informants' varied responses and their ability to express themselves.

\section{RESULTS}

\section{"I THINK IT'S ABOUT HAVING SEX." EXPERIENCES OF SEX EDUCATION}

The interviews reveal a wide variation among informants in terms of communication and language ability, which is part of the intellectual disability [28]. Some express themselves with single words, while others are very verbal and have an extensive vocabulary. Others use a plethora of words but are unsure of their exact meaning. For example, the meaning of "sex education" is unclear to many. An 18-year old male enrolled in a special education national program considers the question:

R: What is sex education to you?

I: No idea ... but having sex, I think.

The breadth and scope of the question yields many different answers. Some point out that sex education can be about feelings and relationships, while others argue that it is about "how the body works." A 16-year old male informant ponders for a long while when asked, and then responds that he thinks about "love." Even the Swedish National Agency for Education [29] points out that the term "sex and relationships" is vague, and that there is a frequent lack of documentation concerning the didactic aims of the subject.

Most informants find it difficult to remember if they have ever had any sex education. The National Agency's (ibid.) review highlights a large variation in the implementation of sex education, not only between schools but also within each individual school. Some schools provide hardly any education at all, while others have extensive and continuous curricula. According to the National Agency, the unintended consequence is that students have varying degrees of opportunities to acquire knowledge and gain insight into sexuality and relationship issues. This study shows that this seems to apply to special education schools as well. Some of the informants can recall having had sex education if the question is reformulated toward asking if the student has participated in separate group activities for boys or girls. Nevertheless, an 18-year old male informant cannot remember if he had sex education or if he was involved in a boys' group. Yet he points out that it is "an important subject" and says that "it is good to learn, so that there won't be any misunderstandings."

Some say that they indeed had sex education, but it was "too little or too difficult to understand," and therefore they would like more information. It is also important to understand the knowledge conveyed in the subject. The informants all agree that "once you have understood and feel you have been able to absorb the knowledge, self-esteem increases." At the same time, it is difficult to exemplify what is missing and what one wants to learn. This is where some become uncertain, perhaps because it is difficult to specify what is missing if there is a lack of basic knowledge. But it can also mean not wanting to 
appear dissatisfied with what has actually been taught, or the desire to gain a deeper knowledge of the subject. A 16-year old boy talks about the sex education he received in sixth grade and wonders:

I: Well, I didn't think... we learned so much. We talked about it ... about how babies are made ... and how to have sex ... and then we had to visit the youth clinic and ask some questions.

R: What was it that was not good? Or what did you want more of?

I: (silence) Perhaps more knowledge about it. I would have wanted to know.

R: Like what for instance?

I: For example about STDs... and how a child is made. No, I know, but I would have liked more knowledge about such things.

A few students have attended combinations of regular primary and/or secondary or high school special education. This also means having experienced how sexual education has been taught in a variety of educational formats. The National Agency for Education [29] review shows that important determinants of whether and how sex and relationship education is conducted involves the existence of clear guidance and a deliberate discussion among teachers, pupils and other stakeholders regarding the meaning of the concepts of sexuality, relationships and gender equality. An 18-year old girl says:

So, when I was in high school (in special education school) ... then we talked a little about your body, like if you eat a lot of chocolate, then you get pimples in your face and that the myth was not true. [...]. But when I went to normal school, then it was just about condoms ... and diseases! They were really like this: "If you get HIV, then your life is over! And you just thought, what if someone has HIV in the class. It was the worst anxiety! You've got to have a condom, remember; condom, condom!"

The review further shows that special education schools have attained a somewhat elevated status among state educational institutions, mainly because they all demonstrate a wellplanned, goal-oriented education that is constantly evolving, unlike many other schools where teaching is not coordinated or documented. 


\section{"THE EGG WILL HATCH IN THE MOMMY'S TUMMY AND THEN THE BABY COMES OUT" KNOWLEDGE ABOUT SEXUALITY}

The informants point out that "knowledge of how the body works is important," and state that this is also the educational focus among teachers. The review by the National Agency for Education [29] shows that half of the surveyed schools place importance on anatomy and biology, while there is less emphasis on gender identity and interaction between boys and girls, and providing support to young teens during adolescence (a so-called promotion perspective). A 19-year old boy who attends a vocational training class says:

So we talked about that stuff like when the hair comes in and then ... when the sperm comes. I think this is ... I listened to it a lot.

Although the informants say they have learned "how babies are made" and how to avoid becoming pregnant, many have an unclear picture of how reproduction occurs. An 18- year old girl who attends a business vocational training class describes the process:

It is woman and man. He has a weenie. And then he is close to the mommy's stomach. And then the egg is cracked in the mommy's tummy and comes out! In different ways, from here (points between her legs) or here on the stomach.

Sex education in special education schools is also focused on the importance of protected sex and the use of contraception, especially condoms, informants say. In addition to anatomical knowledge, this is something that the interviewees find to be the most significant information. A 17-year old girl who attends art class tells of a loved one's experience that greatly influenced her:

I: I learned that if you do not have a condom, you can get diseases down there.

SR: Yes, mhm. And it's important to know this?

I: Yes, it is. Because my sister had a disease down there, because it had broken down. Now it is cured.

The National Agency for Education [29] review shows that the younger the individual, the more the education has to provide context and promote certain concepts, with the teacher proceeding from the experiences and questions posed by the children. Instead, several of the informants in this study say that they received information when they were too young. For example, some in the lower age groups had to practice putting a condom on a dummy, which was experienced as embarrassing, particularly for the girls. An 18-year old girl tells of sex education in sixth grade:

I: And you would, like, put on condom on a fake cock (laughs)!

SR: Well (laughs)! And how was it? 


\section{I: Embarrassing!}

Additional examples of issues that come up too early according to informants are childbirth films, which have been perceived as frightening. An 18-year old girl who is enrolled in a national special education program, says the experience has deterred her from having children in the future. She says indignantly:

And then she also showed a film about how a child is born ... and after that, I would NEVER want to have children! No, never children ...! Some even have to get cut [refers to episiotomy], ugh! [...]. No, then it's more organic to adopt!

But sex education should not just be about pregnancy, sex and puberty, the informants point out. It is also important to address relationships, love and friendship. Among the female interviewees, there are several who mention that they talk more about relationships and friendships than about sexuality in their girls' groups. An 18-year old girl attending a business vocational training class says:

I: Friendship!

SR: Yes. You think that was good?

I: Yes!

SR: Would you have liked to have more of it?

I: Yes, I would!

Love is also a common theme raised in the girls' groups. A shy 20-year old girl says they talked about what love looks like in her group. She explains what they learned:

I: (quietly) You meet a boyfriend. You can go out.

SR: Yes?

I: In the evenings and during the day.

SR: Have you had a boyfriend?

I: Yes.

SR: Was there something you were wondering when you had a boyfriend?

I: How to hold hands.

SR: How to hold hands?

I: Kissing and stuff. Go to the bar.

SR: Yes? 


\section{I: Romantic vacations.}

SR: Mhm.

I: Invite someone to dance.

Loneliness, alienation and bullying are urgent topics that several informants want to discuss, which is also evident in Furenhed's [30] interview about life for young people with ID. Many are interested in finding out how to get into a relationship with someone. Several of the informants are shy and quiet, and say that it is difficult to find a partner and to know how to flirt. An 18-year old male says:

It is ... how to get a girl and stuff. I've got difficulties with it [...]. ... I have problems. I can't find a girl that I like. So ... I have a friend who ... has like ... who can flirt with girls and stuff ... [...] I usually get tips on how sometimes. He's pretty good at it. Sometimes I get tips and sometimes I don't.

Generally, sex education is focused on heterosexuality, informants say. Those in the smaller group who have had homosexual experiences and/or who perceive themselves as lesbian, gay, bisexual or transgender are therefore likely to feel even more on the outside. Research shows that schools serve as a "heterosexual factory," where standards for what is good in life is created through policy documents, teaching materials, instruction and social activities [31]. A 19-year old young man enrolled in vocational training says:

I: Umm ... we talked a little bit about it too.

SR: Do you think it was good or bad?

I: It was good because I myself have ... been with a guy before.

Although research shows that the majority of young people today have seen pornography, either voluntarily or involuntarily [8], informants unanimously state that this is not an urgent matter to discuss during sexual education. Conversely, several informants talk about the risks of being on the Internet, and believe that this is an important issue to discuss. In addition, some point out that you can get into trouble in real life, and it is important to avoid this as well. Other research shows that young people with ID view the risk of never experiencing anything positive or "good" as greater than the risk of becoming involved in something negative or "bad" [4].

\section{"I ALWAYS FORGET WHAT WE HAVE LEARNED"- DIFFERENT WAYS OF LEARNING}

Many of the informants state that they have learning disabilities of varying degrees, which in itself is part of the intellectual disability [see 28]. A 17-year old girl says she does not know the reason for why she has such a hard time remembering things, and that "it feels unfair" when she compares herself to her sister who has it very easy in school. She says: 
I: My teacher can say something, and the next day I forgot it! So, like, after two months it comes back again!

SR: Uh, how is it that it comes back again?

I: I don't know ... And when my sister has a test, then she can read it once and and then she knows it! Don't know why it is that way.

Different degrees of difficulty in understanding, concentrating and focusing exist among all the informants. Some describe that it is easier to remember when one is interested in the topic, which includes most of the informants when the topic concerns sex education. A 17year old boy enrolled in the national special education program reflects and says:

I think if it is exciting, like this, then you remember. But if it is stuff ... that isn't that attention-getting, then you don't care. [...]. So like this (sex education) course, I think is interesting.

Several offer suggestions of how learning could be facilitated. This elucidates the importance of learning in different ways, such as reading books, watching films, role playing and discussion, all of which has been shown as meaningful in other research [32,33]. Several of the informants state that it is difficult to restrict the topic to discussion only. Some suggest RFSU's (the Swedish Association for Sexuality Education) new educational film ${ }^{2}$, which during the time of the interviews aired on television in a series of episodes. A 17-year old girl attending art class explains why she likes to watch films:

Well, that's where you learn ... because when you've seen it on film ... then you have it inside your head and stuff ... When you talk about it, then you usually forget about it and stuff.

Specific living conditions and individual life situations play major roles in human sexual socialization [32], which is something that becomes abundantly clear in the case of a disability. An 18-year old girl who attends business vocational classes communicates by using both speech and sign language. She says she has learned on her own by reading books:

SR: Can you give examples of what you have read?

I: A book about the body.

But not all informants are able to read proficiently [cf. 28]. Some provide tips on how to use audio books. An 18-year old girl points out that it is better to have read several different books, and suggests that the teacher or a student reads aloud in class. She explains that they

\footnotetext{
2 "Sex on the map" is a cartoon that speaks clearly and is based on young people's own questions. The film is meant to be used for sex education in high schools. The film is produced by RFSU and UR with support from the Heritage Fund, Sweden. (http://www.rfsu.se/sv/Sexualundervisning/RFSUmaterial/Sex-pa-kartan--filmen/) Accessed 10 September 2011.
} 
had read a book that was used during sex education class in high school and that it was difficult for many:

It would have been better if they (the teachers) had that knowledge in school ...

because for some, it's difficult to read for yourself ... in your head ... And some want to read aloud.

Some informants provide accounts of different TV shows that contain information about sex and relationships. A 17-year old girl who attends art class offers tips on a documentary about teenaged mothers. She says that "it is good that you are taught that condoms can break," and that it is hard being a mother when you are so young:

But protection does not usually help much ... it can break ... and stuff ... And they have shown that on MTV ... they show teenagers and moms there...and how much difficulty they have ... when they have school and then stop if the child ... and then the dads don't come around and help and stuff... They just split... [...]. You learn that it will be very hard ... to have a baby and stuff ... how much ... pressure there is... and how much it will hurt and stuff ...

Many highlight the need to discuss what is perceived as important and urgent in smaller groups. Most also believe that it is better to have gender-divided groups, as it may be embarrassing to talk about sexuality with both girls and boys in the same group. A 17-year old boy says that it is easier to talk to other boys in group:

$\mathrm{R}$ : Why is that? Are there different issues and thoughts on that?

I: Maybe not, but guys may have private things for themselves. Perhaps there are girls who also don't want to talk in front of guys.

In contrast, some believe that it is a good idea to maintain mixed groups in order to hear what others say and think. Informants also suggest that another way of interacting is to separate the genders and then bring them together in a mixed group. But one 18-year old girl points out that despite some benefits of everyone being together, there is an enhanced feeling of safety in gender-separated groups, because the idea of sexuality from a gendered perspective is different [cf. 21]. She continues:

At first I thought that it doesn't matter, but actually it would still feel pretty safe ... [...] ... if you're talking to a girlfriend, they don't care ... "Like, I had sex with eight guys" ... they don't care ... but if there are guys, it's like "eight? And maybe they think "she's so ugly"...or "what a slut she is" [...] So I don't know what they think, and that's why you have to be a little ... they may think differently, but girls don't care as much.

Only a few suggest role playing and/or exercises to examine values as pedagogical method, even if it is often suggested in the educational guidelines for sex education [e.g. 34]. One explanation may be that many are unfamiliar with these concepts. A 19-year old girl lights 
up when she hears examples of what this could mean. She then says that it may be important to offer tips on how to break up or get together with someone:

I: Some dare calling, some just like dare to look [...]. You want to, but nothing happens!

SR: Are there important tips to tell one another?

I: Yes, there are ... so you can get help.

Some informants have positive experience of seeing theater actors who have exemplified the various situations and events related to sex and relationships, particularly in interactive theatrical performances where the audience and actors communicate in order to solve a particular problem[see 35]. Informants report that discussions occurred sometimes directly during the performance and other times afterwards. A 17-year old girl enrolled in the arts program says:

There was a guy who played many roles ... He would be gay and stuff [...]. Then he put on a dress ... and then he sat at a mirror and put on makeup ... And then he turned around - and we were totally shocked (laughs)! [...]. Then he sits next to a teacher - a man - and he just like goes "hey, baby"! And we all laughed ... And then ... he talked about how we girls ... when we have our periods and stuff ... he had pads with ... there was blood and stuff on it ... I thought it was really fun!

A few additional informants offer the hint that it is easier if you have permission to write down things on paper. Remembering things is easier, because "you can look at it the same time and then see what you wrote down afterwards." Another suggestion of how to improve teaching and to a greater extent base it on the students' needs, is to write questions in advance and put them in an anonymous box. But not all informants believe that this is good for older teens; a 17-year old male participant in the national special education program is in doubt, and believes it is too childish. Instead, he suggests that students be allowed to write their own stories, and tells of a school where 14-year olds were given the task of writing erotic short stories:

I: But it's good! It's a good thing anyway. So there's nothing wrong. It is a good age. There is nothing wrong to write about your sexual experiences.

SR: They did get to choose if the stories had to be true or not, didn't they?

I: Yes, you could write a dream.

SR: Yes, a fantasy.

I: It would have been cool to do that! Your dream girl (laughs!) 


\section{"I WANT SOMEBODY TO TALK TO"- WHAT AND WHEN TO LEARN}

Only a few of the informants report that they have talked to friends about sex, and that this is also how they obtained their knowledge. These informants are attending the national special education program, and have a mild intellectual disability that presents opportunities to read and study some information on their own. Other interviewees agree that the school has been the main source of knowledge acquisition, which is also confirmed in other research [32]. This seems particularly clear for most youth attending special education schools, where many state that they do not have anyone else to talk to - not even friends, parents or siblings. An 18-year old girl says she does not really want attend special education high school at all, nor would she talk to someone about how sad she feels deep inside. She says:

I: No, I'm not talking that much with my parents.

SR: Oh, I see. Do you have brothers or sisters you can talk to?

I: No, I'm not talking to him either. I'm not talking to anyone (starts crying).

Several of the informants would prefer to speak to a familiar teacher, e.g. the home room teacher or another professional in charge of sex education, since it may be a sensitive issue to speak about sexuality with someone unfamiliar. A 16-year old boy reflects:

... Maybe your regular teacher if you feel...shy...the one you speak to often anyway.

A 17-year old girl who attends art class points out that gender is the most important; it should be a woman who provides sex education to girls. It is not really important if she is a teacher at the school or elsewhere. Others suggest that it should be someone who comes from outside and provides sex education, e.g. from the youth clinic, RFSU (the Swedish Association for Sexuality Education) or simply from another school. An 18-year old youth asserts that it is good if teacher and student know each other previously, and that the individual should have a sense of humor. A 17-year old boy attending the national program prefers that it should be someone from the youth clinic:

I: It would be good! That somebody says what to do. So that you don't get it wrong. And she gets pregnant! No one wants that. I want to get it right!

SR: Yes. So that teacher would talk a lot? Explain a lot?

I: Yes, exactly. How to have sexual intercourse with a girl so she won't get pregnant. That might not be a lot of fun. [...].. It is important to know!

Previous research shows that informants emphasize the importance of instruction being repeated, since the interest and relevance of the information is perceived differently according to the adolescent's age group and life stage [32]. As previously noted, it is 
important not to provide information too early. An 18-year old girl says she did not understand everything that was discussed when she was younger, but she has since matured a lot. For example, finding out about the age of consent and physiological responses to sexual stimuli is important to 14-15 year-olds. A 19-year old male who is in the third year of a vocational training class tells us that he had sex education for the first time when he was in his first year of senior high school:

SR: You did not have it in junior high?

I: No.

SR: Do you think it was good that you had it for the first time in senior high school or should it have happened earlier?

I: It should have been earlier ... I like it.

According to the informants, it is "good to have sex education when you are 16-17 years old, because then it's actually about how to have sex and how you protect yourself from pregnancy and STDs. It is also good to discuss that you should have sex when you really want to, and not because you think everyone else has." A 19-year old girl says she had sex education in sixth grade the last time, but feels it was too early. She says:

I: It would have been better to, like, have it now when you are older and ... everybody has boyfriends and girlfriends now. We actually have sex now.

SR: Mhm, that's the way it is in the class?

I: Yes.

Informants state that "when you are 19-20 years old, you want to talk about what it is like to be with someone, if you want to be with many or just one." Moreover, it is good to know how to break up. "Then you are more mature and want to talk about relationships and emotions." The need for young people with ID to talk about sexuality and life issues has been confirmed in a study by Furenhed [30]. Informants stress that it is important to experience moments where they can express their views in casual conversation as well as and in deeper conversations about life.

\section{DiscuSSION}

\section{THE RESTRICTIVE SCRIPT}

In summary, the informants in this study provided clear and in many respects consistent responses to what they believe that sex education should include, when they should be taught, by whom and how. It is evident that many are unsure whether they had obtained any sex education at all, or even grasped the content of the topic; instead the informants are more familiar with the didactic activities in gender-segregated youth groups. They want to understand sexual functions as well as relationships, and they want the information to be 
provided in stages, depending on what is going on in their own lives. About half of the informants want to receive instruction from an individual who is familiar to them in their educational institution, while the remaining interviewees prefer someone from outside. Many affirm that it is good if the learning experience takes place in smaller "girl and boy groups." At the same time, there is a reluctance to criticize the education they receive; this is both related to the dependent situation they find themselves in as students in relation to teachers, and as a consequence of the intellectual disability itself. Nevertheless, the results may still provide a credible picture of the different experiences of sex education that informants have. Despite their varying backgrounds in terms of disability and schools, they have communicated their experiences of sex education in a relatively similar way. In addition, these results are consistent with another study based on a smaller number of informants with ID [36].

Then what is the content of the "manuscript" being is directed at young people with ID during sexual education? Let us begin by distinguishing between implicit and explicit manuscripts [cf. 20]. The latter includes the importance of using contraception and/or protection against unwanted pregnancies and sexually transmitted diseases, the unwanted aspects of being exposed to pornography, and to avoid sexual risk situations. The implicit script highlights heterosexual norms, which, in addition to heterosexual ideals, includes the preferable avoidance of sexual intercourse, and to express love and friendship to a greater extent than sexual feelings. The reasons for this overly restrictive script can be attributed to earlier research, where a general sense of responsibility for the young person's sexuality has been an important factor [4,9]. Based on concerns about the "darker" sides of sexuality, young people with ID become overprotected; in addition, educators are seldom provided continued education on the subject, thereby restricting teachers to their own frames of reference as the basis for the content and format [18]. These are often linked to the prevailing cultural script that is influenced by overall restrictive values in society regarding sexuality and people with ID [cf. 20]. Chivers and Mathieson [37] highlight the importance of providing staff with opportunities to reflect on the dominant professional discourse in which sexuality seen as merely a biological function where sex is focused on deleterious aspects and defines sex as equal to intercourse. These social constructions of sexuality should be challenged and replaced by a discourse that includes desire, pleasure and intimacy (ibid).

In examining how young people describe their needs and desires of how sexual education should be communicated, we find that they draw much from the same restrictive manuscript. Then how can this be interpreted? Olsson [32] states that assumptions questioning sexuality and relationships are essentially about identity. It is not enough to provide factual knowledge; opportunities for reflection and processing of ideas, thoughts and values about sexuality must be given, in order for adolescents to find their "inner compass" (ibid.). A positive view of sexuality and a health promotion perspective are important protective factors for effective sex education; however, if an individual with ID is met with a "wait" and/or "learn to say no" message, chances are that he or she will internalize a negative self-image and sexuality. Olsson [32] speaks of "an exclusionary 
pedagogy," which means that certain ways of being or feeling are more or less unconsciously excluded. Thus, if individuals are named and described by others in a manner consistent with the myths and expectations attributed to a person with ID, then those descriptions may become intrinsic truths internalized by the disabled individual.

\section{A PEDAGOGY CRITICAL OF NORMS}

How can we understand the ways in which knowledge has been transmitted, based on what the informants have reported? Research has shown that it is unusual for adolescents with ID to learn about sexuality from each other, or even unintentionally when spontaneous opportunities arise outside the classroom [38]. The sex and relationship curriculum of special education schools is therefore particularly important, as informants point out. But the heteronormative perspective that has emerged shows that teachers need theoretical tools and models to raise awareness of their own values and standards. According to a critical pedagogy approach, sexuality is viewed as a valuable aspect of life rather than a risk factor (ibid.), which in turn becomes helpful in creating a balance between young people's own needs and the concerns of others. By implementing critical pedagogy, subtle sexual standards and codes can be taught in a concrete way, so that young people with ID may learn to assume responsibility for their own sexuality (ibid.). This allows the young with ID to develop skills and strategies, in order to take responsibility for their sexual expression and their needs.

Bromseth and Darj [34] speak of a critical pedagogy with standards that questions gender and sexuality norms, but also includes color, ethnicity, functional ability and class. This promotes a perspective that can serve as a tool to show how different norms interact and create power imbalances within different pedagogical practices, and how to progressively develop alternatives (ibid. p.13). The study at hand found that adolescents with ID are rarely given the opportunity to examine heterosexual norms, and that informants believe it is because there are only a few who are gay or bisexual. This "exclusionary pedagogy" [32] should therefore be challenged by school staff proceeding from a pedagogy critical of norms. It also means that staff in special education schools should base their perspective on the sex education used in a standard curriculum and not transform it into a "special" perspective in which the intellectual disability is the focus; otherwise, there is a risk of missing potential capacities, individual variations and finding out what other factors may be relevant among this population. The informants in this study have pointed out the various options that facilitate learning, but even so, they have not wished for any special education based on their disabilities. Thus, an adapted model for sex and relationship education consistent with adolescents' varying individual circumstances is as well suited to individuals with ID as to any other young people who are not included in a homogeneous group.

Future studies should therefore to a greater extent include youth with ID as both participants and collaborators in research. The intent would be to capture the more complex and subtle contexts, including a clearer gender perspective, which needs to be made visible in order to create an education and an attitude that favors the possibility for 
these young people to find their own "internal compass." Such studies may provide adolescents with ID increasing opportunities for learning strategies to reduce sexual risks and sexual disorders, and thereby increase the prospects for the promotion of the more affirmative and positive aspects of sexuality. 


\section{REFERENCES}

1. WHO, World Health Organization: Definitions on sexuality. International WHO Technical Consultation on Sexual Health (28-31 January), (2002)

2. Bäckman, M.: Sex- och samlevnadsundervisning i skolan. [Sex and relationship education in school]. In: Lundberg, P.O., Löfgren-Mårtenson, L. (eds.) Sexologi [Sexology], 3rd edn., pp.423-429. Liber förlag, Stockholm (2010)

3. Nilsson, A.: Hela livet. 50 år med sex- och samlevnadsundervisningen. [The entire life. Fifty years with sex and cohabitation education]. Myndigheten för skolutveckling. Liber förlag, Stockholm (2005)

4. Löfgren-Mårtenson, L.: Får jag lov? Om kärlek och sexualitet i den nya generationen unga med utvecklingsstörning. [May I? About love and sexuality in the new generation of youth with developmental disabilities]. Studentlitteratur, Lund (2005a)

5. Murphy, N.A., Elias, E.R.: Sexuality of Children and Adolescents with Developmental Disabilities. Pediatr. 118, 398-403 (2006)

6. Socialstyrelsen: Att förebygga HIV och STI bland ungdomar och unga vuxna. Kunskaper och vägledning för hälso- och sjukvården och andra intresserade aktörer. [Prevention of HIV and STIs among adolescents and young adults. Information and guidelines for healthcare and medical services, and other interested parties]. Socialstyrelsen, Stockholm (2009)

7. Löfgren-Mårtenson, L.: Hur gör man? Om sex- och samlevnadskunskap i särskolan. [How do you do it? On sex and relationship education in the special education school]. Argument förlag, Varberg (2009a)

8. Löfgren-Mårtenson, L., Månsson, S.-A.: ”Sex överallt, typ?!” Om unga och pornografi. [Sex, like everywhere?! On youth and pornography]. Förlagshuset Gothia, Mölnlycke (2006)

9. Löfgren-Mårtenson, L.: Kärlek.nu. Om Internet och unga med utvecklingsstörning. [Love.now. On the Internet and youth with developmental disabilities]. Studentlitteratur, Lund (2005b)

10. Svedin, C.-G., Priebe, G.: Ungdomars sexualitet - attityder och erfarenheter. [Sexuality of adolescents - attitudes and experiences]. Avd. för Barn- och ungdomspsykiatri, OPUSinstitutionen, Lund (2004)

11. Kullman A.: Begåvningsnivå och psykiska problem en undersökning av en kohort tvångsvårdade flickor och kvinnor. [Level of talent and psychological problems: a cohort survey of institutionalized girls and women]. Institutionen för psykologi, Lunds universitet, Lund (2007)

12. Abbott, F., Howarth, J.: Secret loves, hidden lives? Exploring issues for people with learning difficulties who are gay, lesbian or bisexual. The Policy Press, Bristol (2005)

13. Löfgren-Mårtenson, L.: The Invisibility of Young Homosexual Women and Men with Intellectual Disabilities. Sex. Disabil. 27(1), 21-26 (2009b)

14. Grönvik, L. : Sexualitet och funktionshinder. [Sexuality and disability]. In: Grönvik, L., Söder, M. (eds.) Bara funktionshindrad? Funktionshinder och intersektionalitet [Just disabled? Disability and intersectionality], pp. 47-63. Gleerups, Malmö (2008)

15. Barron, K.: Genus och funktionshinder. [Gender and disability]. In: Barron, K. (ed.) [Gender and disability], pp. 15-52. Studentlitteratur, Lund (2004)

16. Gunnarsson, E., Szebehely, M.: (red.) Genus i omsorgens vardag. [Gender in every day caregiving]. Gothia förlag, Stockholm (2009)

17. Löfgren-Mårtenson, L.: Sexualitet och integritet. Om anpassad sex- och samlevnadskunskap för personer med utvecklingsstörning. [Sexuality and integrity. On sex and relationship education adapted to persons with developmental disabilities]. Studentlitteratur, Lund (1997) 
18. Hållö. J.: Sex och samlevnadsundervisning i grundsärskolans åk 6-10 och gymnasiesärskolans nationella program. [Sex and relationship education in special education primary and secondary national programs]. Lärarutbildningen, Malmö högskola, Malmö (2010)

19. Richters, J.: The social construction of sexual practice: setting, sexual culture and the body in casual sex between men. Department of Public Health and Community Medicine, University of Sidney, Sydney (2001)

20. Gagnon, J., Simon, W.: Sexual conduct. The social sources of human sexuality, 2nd edn. Aldine Publishers Company, Chicago (2005)

21. Forsberg, M. Brunetter och blondiner: sex, relationer och tjejer i det mångkulturella Sverige. [Brunettes and blondes: sex, relations and chicks in multi-cltural Sweden]. Studentlitteratur, Lund (2007)

22. Kvale, S.: Den kvalitativa forskningsintervjun. [The qualitative research interview]. Studentlitteratur, Lund (1997)

23. Starrin, B., Renck, B.: Den kvalitativa intervjun. [The qualitative interview]. In: Svensson, P.G., Starrin, B. (eds.) Kvalitativa studier i teori och praktik [Qualitative studies in theory and practice] , pp. 52-78. Studentlitteratur, Lund (1996)

24. Booth, T.: Sounds of still voices: Issues in the use of narrative methods with people who have learning difficulties. In: Barton, L. (ed.) Disability and Society. Emerging Issues \& Insights, pp. 237-255. Longman, London (1996)

25. Tøssebro, J.: Institusjonsliv i velferdsstaten. [Institutionalized life in the welfare state]. Ad Notam Gyldendal, Oslo (1992)

26. CODEX: Etiska regler och riktlinjer för forskning. [Ethical rules and guidelines for research]. Vetenskapsrådet, Uppsala universitet. http://www.codex.vr.se/ (Accessed 9 October 2011).

27. Widerberg, K.: Kvalitativ forskning i praktiken. [Qualitative research in practice]. Studentlitteratur, Lund (2002)

28. Granlund, M., Göransson, K.: Utvecklingsstörning. [Developmental disability]. In: Söderman, L. Antonsson, S. (eds.) Nya Omsorgsboken [The New book of Long-term Care], pp. 12-19. Liber, Malmö (2011)

29. Furenhed, R.: Livet och frågorna. [Life and questions]. In: Söderman, L. Antonsson, S: (eds.) Nya Omsorgsboken [The New book of Long-term Care] [The New book of Long-term Care], pp. 119-128. Liber, Malmö (2011)

30. Skolverket: Skolverkets nationella kvalitetsgranskningar. [The national quality review of the National Agency for Education]. Skolverket, Stockholm (1999)

31. Røthing, Å., Svendsen, S.: Homotolerance and Heterosexuality as Norwegian Values. J. LGBT Youth, 7(2), 147-166 (2010)

32. Olsson, H.: Sexatlas för skolan. Vägvisare för att planera och genomföra sex- och samlevnadsundervisning i grundskolan och gymnasiet. [Sex atlas for schools. Roadmap for planning and implementation of sex and relationship education in primary and secondary schools]. RFSU, Borås (2003)

33. Stettini, P.: Improving the quality of sexuality education programs: emerging evidence from research, relevant challenges for sexology. Sexol. 17(1), S39. (2008)

34. Bromseth, J., Darj, F.: Normkritisk pedagogik. Makt, lärande och strategier för förändring. [Critical norm pedagogy: power, teaching and strategies for change]. Centrum för genusvetenskap, Uppsala universitet, Uppsala (2010)

35. Boal, A.: Theatre of the oppressed, 3rd edn. Pluto Press, London (2000) 
36. Swango-Wilson, A.: Meaningful Sex Education Programs for Individuals with Intellectual/Developmental Disabilities. Sex. Disabil. 29, 113-118. (2011)

37. Chivers, J., Mathieson, S.: Training in Sexuality and Relationships: An Australian Model. Sex. Disabil. 18(1), 73-80. (2000)

38. Gougeon, N. A.: Sexuality education for students with intellectual disabilities, a critical pedagogical approach: outing the ignored curriculum. Sex. Educ. 9(3), 277-291. (2009) 